\title{
DID MOSES PERMIT DIVORCE? MODAL wĕqātal AS KEY TO NEW TESTAMENT READINGS OF DEUTERONOMY 24:1-4
}

\author{
Andrew Warren
}

\section{Summary}

The New Testament discussions of divorce, both in Matthew 19 and elsewhere, are dominated by a distinction between Permission and Obligation. It is generally assumed that the debate arises from a 'presupposition' of divorce in Deuteronomy 24. An improved syntactic analysis of the Old Testament text shows Moses to have in fact issued a specific directive on divorce, but in such a way that it was open to the kind of misunderstanding that we see corrected by Jesus. This analysis is supported by all the New Testament texts. By applying the categories of linguistic modality to main-clause verbs, verbs of reporting, verbs of divorcing and conditional clauses, it is possible to shed more light on how Jesus and the Pharisees dealt with the Old Testament text, and to show just what was wrong with the Pharisees' understanding of Hebrew grammar.

\section{Modal Force: Permissive and Obligative}

The study of modality conventionally ${ }^{2}$ distinguishes between the Epistemic (modality of knowledge, e.g. subjunctive) and the Deontic (modality of volition, e.g. imperative). Each of these systems includes weak ('may') and strong ('must') modal force. In Epistemic terms, these represent respectively Possibility and Necessity; in Deontic terms, Permission and Obligation. ${ }^{3}$ Hence the following schema:

\footnotetext{
${ }^{1}$ This paper is greatly indebted to discussion with, and forthcoming publications of, David Instone Brewer, Research Librarian at Tyndale House.

2So, for example, in the relevant sections of F.R. Palmer, Mood and Modality (Cambridge Textbooks in Linguistics; Cambridge: CUP, 1986) and J. Lyons, Semantics, 2 vols. (Cambridge: CUP, 1977).

${ }^{3}$ These and other key terms are capitalised in the following for clarity.
} 


\begin{tabular}{l|l|l} 
& $\begin{array}{l}\text { EPISTEMIC } \\
\text { 'It is so' }\end{array}$ & $\begin{array}{l}\text { DEONTIC } \\
\text { 'So be it!' }\end{array}$ \\
\hline WEAK & Possibility & Permission \\
'I don't know' & 'It may be raining.' & 'You may come in.' \\
\hline STRONG & $\begin{array}{l}\text { Necessity } \\
\text { 'It must be raining.' }\end{array}$ & $\begin{array}{l}\text { Obligation } \\
\text { 'You must come in.' }\end{array}$
\end{tabular}

The Deontic morphological mood, the 'imperative', may be used to express weak or strong modal force-'Come in!' may be an expression of Permission or Obligation. These categories may help in understanding New Testament interpretations of Old Testament instructions on divorce. 4

\section{New Testament Interpretations: Pharisees reading Obligative and Jesus Permissive}

In Matthew 19, on the question of Moses's attitude to divorce,

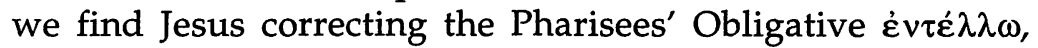
'command', to Permissive غ̇ $\pi \imath \rho \varepsilon ́ \pi \omega$, 'allow':

Some Pharisees came to him, and to test him they asked, 'Is it lawful for a man [ $\varepsilon \dot{\varepsilon} \ddot{\varepsilon} \xi \varepsilon \sigma \tau \imath v \dot{\alpha} v \theta \rho \omega \dot{\pi} \omega]$ to divorce his wife for any cause?'... They said to him, 'Why then did Moses command us to give a certificate of dismissal and to divorce

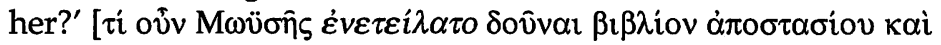

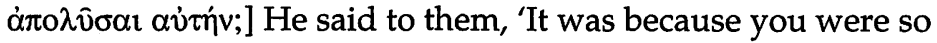
hard-hearted that Moses allowed you to divorce your wives

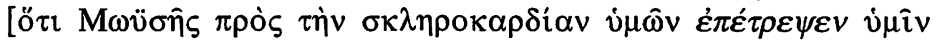

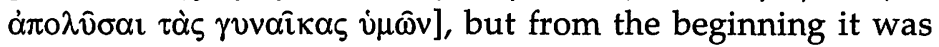
not so....' (Mt. 19:3-9, NRSV)

Hays comments on these readings of the Law as follows:

The distinction between permission and command, marked by the verbs employed in this exchange, provides the basis for Jesus to escape the charge of opposing Moses: the Torah

4These categories are also applied to the Hebrew of the Psalms in my doctoral thesis, and to other New Testament texts at the end of this paper. 
certainly does not mandate divorce. Indeed, the passage in question, Deuteronomy 24:1-4, presupposes the practice of divorce and merely prohibits a man from remarrying his divorced wife after an intervening second marriage; that is the only commandment actually stated in the passage. The certificate of divorce was no doubt originally intended as a document of legal protection for the woman, proving that she was free to remarry; again, however, this is presupposed rather than legislated by Deuteronomy 24:1.

In the following, I hope to show that, far from 'presupposing' the procedure for divorce, Deuteronomy 24:1 does in fact legislate upon it, and, moreover, in such a way that both 'permission and command' can naturally be read. I try to show from a grammatical perspective why a Permissive reading must be correct.

\section{Deuteronomy 24 węqațal Permissive or Obligative}

Deuteronomy $24: 1-4$ is a case law, prohibiting remarriage to one's former wife after she has meanwhile remarried and been divorced again. The syntax of these verses is mostly unmarked, being a series of wĕqațal clauses. I here suggest a reanalysis of the syntax, which gives a new, Deontic main-clause status to the first mention $(\mathrm{v} .1 \mathrm{~b} \beta)$ of the tripartite procedure for a legally valid divorce.

\section{Traditional Reading: weqațalas Conditional Protasis}

The structure of this law has been traditionally understood, since the Septuagint, as a number of protases, leading up to one apodosis in v. 4. So, for example, LXX, RSV, NIV, NASB:

When a man takes a wife and marries her, if then she finds no favour in his eyes because he has found some indecency in her, and he writes her a bill of divorce and puts it in her hand

${ }^{5}$ R.B. Hays, The Moral Vision of the New Testament: A Contemporary Introduction to New Testament Ethics (Edinburgh: T. \& T. Clark, 1996) 34778,350 ; though this appears in Hays's discussion of Mk. 10, he clearly has Mt. 19 in mind. 
and sends her out of his house... then her former husband... may not take her again... (Dt. 24:1-4, RSV)

According to this reading, Moses makes no ruling on the Permissibility or otherwise of divorce. Rather, the whole procedure ('if... he writes... and puts... and sends...') occurs in a subordinate clause as a 'presupposed' (so Hays above) social convention. As Yaron writes,

The execution of a bill of divorce... is mentioned only obiter, as part of the relevant facts of the case.... Only the beginning of verse 4 is taken up by the operative provision. 6

\section{New Reading: wĕqațalas Modal Apodosis}

A textlinguistic appreciation of the various shifts in grammatical subject (underlined below) and certain patterns of repetition tends to suggest a new reading of Deuteronomy 24:14 , based on four levels of conditional protasis, all finally resolved in v. 4.7

${ }^{6} \mathrm{R}$. Yaron, 'The Restoration of Marriage', JJS 17 (1966) 1-11, 3. See also C.M. Carmichael, The Laws of Deuteronomy (Ithaca and London: Cornell UP, 1974) 203-7; G.J. Wenham, 'The Restoration of Marriage Reconsidered', JJS 30 (1979) 36-40; R. Westbrook, 'The Prohibition on Restoration of Marriage in Deuteronomy 24:1-4', in S. Japhet (ed.), Studies in Bible 1986 (Scripta Hierosolymitana XXXI; Jerusalem: Magnes, 1986) $387-405$. These scholars are mainly concerned with the reason behind the prohibition in v. 4, whilst here I reanalyse the grammatical relations between parts of the text.

$7 \mathrm{P}=$ protasis; $\mathrm{A}=$ apodosis; subordinate clauses are indented and in smaller type. An alternative analysis might treat v. 4, within the larger apodosis (vv. 1b-4), as resolving the compound protasis vv. $1 b-3$ (a) thus:

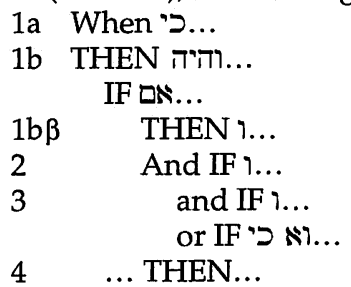

My reading of $1 b \beta$ as apodosis is unaffected. 
yiqtōol

and 1 marries her: wĕqătal

1ba 1ATHEN והיה...

wĕqătal

2PIF aN

$1 \mathrm{~b} \beta \quad 2 \mathrm{~A}$ THEN 1

she doesn't find favour in his eyes

yiqtōol

because ' $\supset$ he has found some indecency in her, qätal he may/must write her a certificate of divorce, wĕqațal I put it in her hand

wĕqațal

and 1 send her from his house.

$2 \quad{ }^{3 P}$ And IF

she goes out of his house

wĕqātal

and 1 goes

and 1 becomes [the wife] of another man

wĕqãtal

wĕqătal

wĕqătal

$3 a$

$4 \mathrm{P}^{1}$ and $\mathrm{IF} 1$ the second man hates her

wĕqațal

and 1 writes her a certificate of divorce, wĕqațal

I puts it in her hand

and $i$ sends her from his house,

wĕqātal

wequațal

$3 b$

${ }^{4 P 2}$ or IF

who איא has taken her as his wife,

yiqtōl

qătal

4a 1A...THEN [Ø] her first husband,

who רשs sent her away,

cannot again take her to be his wife

qātal

yiqtōl

after אחרי אישר she has been declared unclean 8 qätal

for ' $כ$ that is an abomination before the LORD.

$4 \mathrm{~b}$ Thus 7 you will not bring guilt on the land

yiqtōl

which רשs the LORD your God is giving qoțêl

to you as an inheritance.

The traditional reading is undoubtedly correct in considering $\mathrm{v}$. 4 (anticipated in והיה v. 1b) the principal apodosis of the text. However, the wĕqātal form used in v. 1, וכתב, which the traditional reading understands as coordinate ('and if he

${ }^{8}$ Declarative, or more properly, 'delocutive' (D.R. Hillers, 'Delocutive Verbs in Biblical Hebrew', JBL 86 (1967) 320-24) hothpa ${ }^{\varsigma}$ el, that is, hothpa ${ }^{\varsigma}$ el interpreted as equivalent to hoph'al. So Bauer-Leander, $285 \S 38$ j' and (tentatively) Joüon-Muraoka, 159 §53h; contra J.H. Walton, 'The Place of the hutqattelel within the D-Stem Group and its Implications in Deuteronomy 24:4', HS 32 (1991) 7-17 (who reads 'after she has been made to declare herself to be unclean'), Bergsträsser, II 99 §g note (who reads as equivalent to hithpa ${ }^{\varsigma} e l$ ) and Meyer, $2.156 \S 81.4 \mathrm{c}$ (who reads as causative reflexive). This is important, since it supports Westbrook's interpretation of the first divorce as having been based on a legal pronouncement of her uncleanness (ערות דבר). 
writes'), is also the standard verbal form, especially after a conditional marker such as $\mathrm{N}$ ' or ' ('if'), for marking a Deontic apodosis ('then he may/must write'). ${ }^{9}$ Therefore, protasis and apodosis here need to be distinguished by means of lexis and discourse-level features, in particular, by shift in main-clause subject.

The opening formula ...'כ, 'When...' (1P), is often used as the introduction to case laws, and can be read as a title/topic to which והיה, 'and it may/must be...',10 introduces the text/ comment (anticipating v. 4). The next protasis (2P) is then clearly marked by $ם s$, 'if...', and a subject-shift (Man \#1 to Woman). ${ }^{11}$

The first apodosis (2A) can be argued to begin with וכתב as follows. Firstly, the detailing of all three elements ('write... put... and send') shows that the focus here is on the procedure for divorce, not the mere fact of it-this is a stipulation, not a presupposition. Second, 'not finding favour' naturally infers that the husband will act, especially if the ערוה ('indecency') is a sexual impropriety; if 'write... put... and send' were coordinate to this, they would be a superfluous reference to the implementation of his 'not finding favour'. The text is not saying 'If he doesn't like her, and if, what's more, he divorces her', but rather, 'If he doesn't like her, then he may/must write... put... and send...'. Thirdly, there is another subject-shift here (Woman to Man \#1).

The next protasis (3P) is marked by repetition of מביתו ('and if she goes out of his house') after the preceding ושלחה מביתו ('and send her from his house') and a subject-shift (Man \#1 to Woman). The next subject-shift (Woman to Man \#2) marks a distinct sub-protasis (4P1), within which the procedure

${ }^{9}$ See, for example, after as: Ex. 21:8a, 11, 23; after 'כ: Ex. 21:35; Dt. 17:4b (so NIV), 5. B.K. Waltke and M. O'Connor, An Introduction to Biblical Hebrew Syntax (Winona Lake: Eisenbrauns, 1990) $526 \$ 32.2 .1 \mathrm{~b}$.

$10 \mathrm{Or}$, more idiomatically, 'shall', which, it should be noticed, is also volitional, not a pure future (if such exists!).

${ }^{11}$ On the distinction between $כ$ and $ם$ in casuistic law, see R.A.F. MacKenzie, 'The Formal Aspect of Ancient Near Eastern Law', in W.S. McCullough (ed.), The Seed of Wisdom: Essays in Honour of T.J. Meek (Toronto: University of Toronto Press, 1964) 31-44, 35. 
for divorce is spelled out, though its status is this time clearly that of 'given' information. The repetition of האיש האחרון ('the second man') (4P2) shows that $3 a$ and $3 b$ are parallel, both following on from the conditional force of 3P. Finally, the main apodosis is clearly v. 4, marked by prohibitive $\leqslant$, the modal verb 'כל ('can') and a last subject-shift (Man \#2 to Man \#1).

The various levels of conditional dependency and their subject-shifts may be summarised as follows: 12

\begin{tabular}{|c|c|c|}
\hline $1 \mathrm{P}$ & When & M1 marries $W$ \\
\hline $1 \mathrm{~A}$ & $\Rightarrow$ THEN... & \\
\hline $2 \mathrm{P}$ & IF & W displeases $\mathrm{M}$ \\
\hline 2A & $\Rightarrow$ THEN & M1 may/must divorce $W$ \\
\hline $3 \mathrm{P}$ & $\cap \mathrm{IF}$ & $\mathrm{W}$ marries M2 \\
\hline $4 \mathrm{P} 1$ & กIF & M2 dislikes and so divorces $\mathrm{W}$ \\
\hline $4 \mathrm{P} 2$ & UIF & M2 dies \\
\hline $2-3-4 A$ & $\Rightarrow \mathrm{TH} \mathrm{EN}$ & M1 may not marry $\mathrm{W}$. \\
\hline
\end{tabular}

The complexity lies in the way each condition depends on the preceding one, so that the final apodosis is in fact dependent upon and resolves all four levels of condition: the title (1P), the first marriage and divorce (2P/A), the second marriage (3P), and the second divorce or bereavement (4P1/2). In other words, the final ruling 'he may not marry her again' is only applicable if the four preceding compounded conditions have been fulfilled-if a man marries a woman (1P), and divorces her $(2 \mathrm{P} / \mathrm{A})$, she remarries $(3 \mathrm{P})$ and is divorced again or bereaved (4P). ${ }^{13}$

Within this context, it has been shown that v. 1 'write... put... and send' is to be understood as a first apodosis, with the full volitional force of the weqațal form. In contrast to the reading of LXX, RSV etc. above, then, I read:

When a man takes a woman and marries her: If she doesn't find favour in his eyes, because he's found some indecency in her, then he may/must write [וכתב] her a certificate of divorce, put it [ונתן] in her hand, and send her [ושלחה] from his house.

\footnotetext{
${ }^{12}$ Compare Westbrook, 'Restoration of Marriage', 388.

13In Je. 3:1 and Mt. 5:32, the first marriage (1P) and the second divorce (4P) are simply assumed.
} 


\section{3. וכתב as Modal: Permissive or Obligative}

In contrast to LXX, which simply presupposes the procedure for divorce, we have seen that MT as understood above does in fact stipulate a procedure. Only this reading could have given rise to the Permission/Obligation debate found in the New Testament, and this ambiguity lies in the wĕqātal form of ('he may/must write... put... and send...') in Deuteronomy 24:1. Like yiqțōl, wĕqātal most often (if not always) has a modal meaning, which, like that of the subjunctive in many languages, covers the entire modal range from Permissive ('he may') to Obligative ('he must').

Thus the most literal version of Deuteronomy 24:1 found in the New Testament in fact appears in Matthew 5:31 (similarly 1 Cor. 7:15 and Josephus, Ant. 4:253):

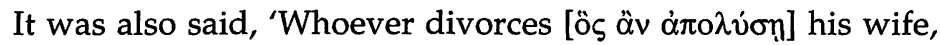

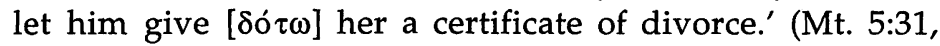
NRSV)

The volition to divorce implied by the Hebrew condition תמצא-חן בעיניו ('If she doesn't find favour in his eyes') is

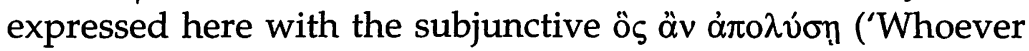
would divorce $\left.{ }^{\prime 14}\right)$. The modality of the wĕqătal apodosis .... וכתב ונתן ('then he may/must write... put'15) then corresponds to that of the third-person imperative $\delta$ ó $\tau \omega$ ('let him give'). Thus this New Testament text confirms my reading of Deuteronomy $24: 1 \mathrm{~b} \beta$ as an apodosis, and of the wĕqätal form as volitional. The Greek third-person imperative (like the English imperative 'Come in!' under 1 above) has the full modal range from Permission to Obligation, as is attested in, for example, Robertson's list of runctions of the imperative: 'Command or

${ }^{14}$ Contra NRSV, which appears to read the subjunctive as due to the indefinite subject.

${ }^{15}$ The Hebrew verb here, נתן, is of course usually translated 'give'; it appears here as 'put' purely for the sake of English idiom with the locative complement 'in her hand'. 
Exhortation', 'Prohibition', 'Entreaty', 'Permission' and 'Concession or Condition'. 16

וכתב... ונתן... considered under Section II above may be summarised as follows:

1. Conditional Protasis ('if he writes...')

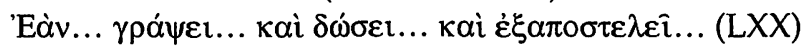

2. Permissive Apodosis ('then he may write...')

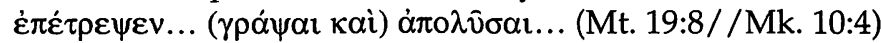

3. Obligative Apodosis ('then he must write...')

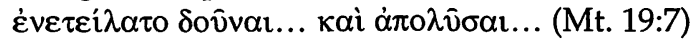

The first interpretation has been ruled out above by discourse analysis of MT, the wording of the dispute in Matthew 19// Mark 10, and the version in Matthew 5. The second and third interpretations are both possible in the third-person imperatives of Matthew 5 and 1 Corinthians 7:15;17 in Mark 10, the Pharisees read Permissive, whilst in Matthew 19, as we have seen, the Pharisees read Obligative and Jesus Permissive.18

16A.T. Robertson, A Grammar of the Greek New Testament in the Light of Historical Research, 3rd edn. (New York: George H. Doran Company, 1919) 946-48. See his various examples, including, under 'Permission', the divorce text in 1 Cor. 7:15: $\chi \omega \rho \imath \zeta \dot{\varepsilon} \sigma \theta \omega$, 'let him leave'. Similarly F. Blass, A. Debrunner, and F. Rehkopf, Grammatik des neutestamentlichen Griechisch (Göttingen: Vandenhoeck \& Ruprecht, 1976) 313 §387.1: 'Der Imperativ... drückt keineswegs bloß einen Befehl aus, sondern auch eine Bitte oder ein Zugeständnis.'

17Similarly, Josephus, Ant. 4:253.

${ }^{18} \mathrm{~A}$ brief note on Mk. 10 is in order here, since it appears to present the roles as exactly the reverse of those in Mt. 19. It is true, as stated above, that the Pharisees here express a Permissive interpretation ( $\varepsilon \xi \varepsilon \sigma \tau \imath v$, $\dot{\varepsilon} \pi \varepsilon \dot{\tau \varepsilon} \psi \varepsilon v)$, but not, in fact, that Jesus expresses the Obligative. The text reads as follows:

Some Pharisees came, and to test him they asked, 'Is it lawful [ $\varepsilon i$ $\left.\ddot{\varepsilon}^{\prime} \varepsilon \sigma \tau \iota v\right]$ for a man to divorce his wife?' He answered them, 'What

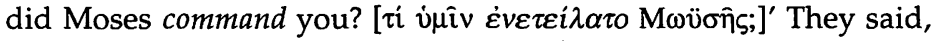
'Moses allowed a man to write a certificate of dismissal and to

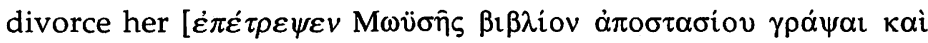
$\dot{\alpha} \pi \mathrm{o} \lambda \hat{v} \sigma \alpha \mathrm{l}]$.' But Jesus said to them, 'Because of your hardness of

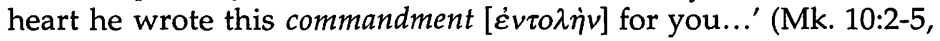
NRSV) 


\section{Inherent Modality: Old Testament Obligative 'send' to New Testament Permissive 'release'}

The formal procedure of the three verbs in Deuteronomy 24:1 and 3 may be summarised from a linguistic perspective as two actions. The first action is the writing and giving of the certificate of divorce; this action is summarised in Mark 10:4 as 'writing' and in Matthew 5:31 and 19:7 as 'giving'. In the second action, sending the woman away (an Obligative action, meaning 'You must go!'), the New Testament makes a modal19 distinction by using the term 'release', which is inherently Permissive ('You may go!').

In the Old Testament, שלח, 'send away' (consistently $\dot{\varepsilon} \xi \alpha \pi 0 \sigma \tau \varepsilon \dot{\varepsilon} \lambda \lambda \omega$ in LXX), is used of divorce together with the term ספר כריתת ('certificate of divorce') in the Law (Dt. 24:1-4) and the Prophets (Is. 50:1; Je. 3:8). It also occurs in other legal restrictions on divorce (Dt. 22:19, 22), a prophetic repudiation of divorce (Mal. 2:16) and the accounts of Abraham's dismissal of Hagar (Gn. 21:1420) and then his concubines (Gn. 25:6). Both the Hebrew and the Greek appear to have the status of technical terms. של is basically Obligative, as is shown by its use for banishment (Gn. 3:23; Is. 16:2), commanding slaves (Gn. 20:2), defeating enemies (Lv. 18:24) and firing arrows (Ps. 18:14). It is clearly Permissive, however, in the request by the man wrestling with Jacob at Penuel that Jacob should let him go:

Though Jesus here uses a verbal and a nominal form from $\dot{\varepsilon} v \tau \dot{\varepsilon} \lambda \lambda \omega$

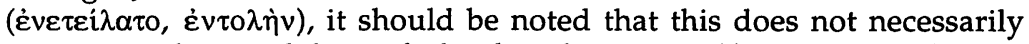
represent the modality of the legislation itself-it is possible to command/prescribe that something is Permissible (though it is not possible to Permit that something is Obligatory-see below, section 6). It is this generic use of $\dot{\varepsilon} v \varepsilon \tau \varepsilon i \lambda \alpha \tau o$ and $\dot{\varepsilon} v \tau 0 \lambda \dot{\eta} v$ that is to be understood here. Further, one might note that the initial question here is slightly different to that in Mt. 19. There, Jesus was asked-at least initially (though see below on the change in v. 7)-about the Permissibility of Hillelite divorce ( $\kappa \alpha \tau \dot{\alpha} \pi \hat{\alpha} \sigma \alpha v$ ai tiav, 'for any cause'); here there is no such specification.

${ }^{19}$ Hence my term here 'inherent modality' for what is usually termed 'fientivity' or 'dynamism'.

${ }^{20} \mathrm{LXX}$ has unprefixed $\dot{\alpha} \pi \circ \sigma \tau \varepsilon \dot{\lambda} \lambda \boldsymbol{\varepsilon} \varepsilon v$ here. 
Then he said, 'Let me go...'

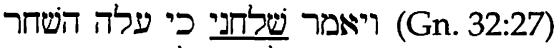

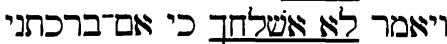

But Jacob said, 'I will not let you go...'

(NRSV)

In the New Testament, $\alpha$ đo $\lambda$ v' $\omega$, 'release', is used in all four main divorce texts in the Gospels (Mt. 5:31-2; 19:3, 7-9; Mk. 10:2, 4, 11-12; Lk. 16:18) as well as in the account of Joseph's intention to divorce Mary (Mt. 1:19); the non-prefixed form $\lambda v \omega$ is used in Paul's discussion in 1 Corinthians 7:27. $\dot{\alpha} \pi \circ \lambda \nu \omega$ is undoubtedly basically Permissive, as is shown by its use for cancelling debts (Mt. 18:27), releasing prisoners (Lk. 23:16-25; Acts $4: 21-23$; 16:35-36 et passim), healing (Lk. 13:12) and forgiveness (Lk. 6:37). However, it is clearly Obligative in the disciples suggestion that Jesus tell the persistent Canaanite woman to go away:21

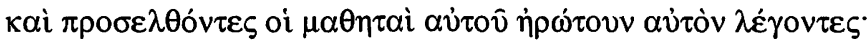

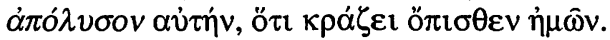

(Mt. 15:23)

And his disciples came and urged him, saying,

'Send her away, for she keeps shouting after us.' (NRSV)

A further context where we see terminology with inherent modality being used with extended meaning is in Paul's treatment in 1 Corinthians 7:10-16. Predominant terms here are $\chi \omega$ pi $\omega$, 'separate' (1 Cor. 7:10-11, 15; also Mt. 19:6; Mk. 10:9) and óфí $\mu \mathrm{t}$, 'send away' (1 Cor. 7:11-13). Hays has argued persuasively for synonymity between these two terms on the basis of the parallel between vv. 10 and 11:22

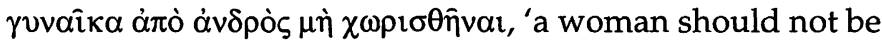
separated from her husband' (1 Cor. 7:10)

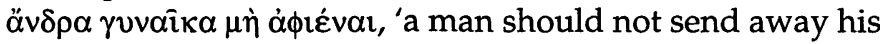
wife' (1 Cor. 7:11)

\footnotetext{
${ }^{21}$ It has occasionally been argued, however, that it is Permissive here, in the sense 'Let her go!', i.e. 'Grant her request!'. See the discussion in W.D. Davies and D.C. Allison, The Gospel according to Saint Matthew, vol. 2 (Edinburgh: T. \& T. Clark, 1991) 549-50.

22Hays, The Moral Vision of the New Testament, 358.
} 
This may, however, be simply a question of active and passive participant roles.

Whilst acknowledging a certain flexibility in the use of all of the terms discussed, we may conclude that essentially Obligative and $\dot{\alpha} \pi \circ \lambda \dot{v} \omega$ essentially Permissive. There has therefore been a striking shift in all the New Testament texts towards a Permissive attitude in a man's divorcing of his wife.

\section{Compositional Modality}

It is well known that the (morphological) aspect of a clause interacts closely with the inherent (lexical) aspect of its verb. Similarly, we may say that the modal force of the clauses with

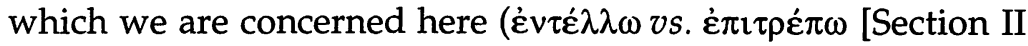
above]; wĕqātal as Obligative or Permissive [Section III.3 above]) interacts with the inherent modality of the terms

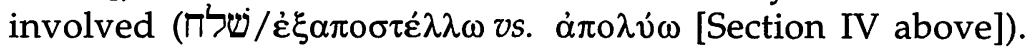
This presents four possibilities:

\begin{tabular}{|c|c|c|}
\hline Clause: & $\begin{array}{l}\text { OBLIGATIVE } \\
\text { wěqātal, } \mathbf{\varepsilon} v \tau \dot{\varepsilon} \lambda \lambda \omega\end{array}$ & $\begin{array}{l}\text { PERMISSIVE } \\
\text { wĕqātal, } \dot{\varepsilon} \pi \iota \tau \rho \dot{\varepsilon} \pi \omega\end{array}$ \\
\hline 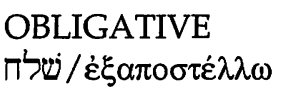 & $\begin{array}{l}\text { 'He must send.' } \\
\text { (Dt. 24:1) }\end{array}$ & $\begin{array}{l}\text { 'He may send.' } \\
\text { (Dt. 24:1) }\end{array}$ \\
\hline $\begin{array}{l}\text { PERMISSIVE } \\
\dot{\alpha} \pi \circ \lambda v ́ \omega\end{array}$ & $\begin{array}{l}\text { 'He commanded } \\
\text { to release.' } \\
\text { (Mt. 19:7) }\end{array}$ & $\begin{array}{l}\text { 'He allowed } \\
\text { to release.' } \\
\text { (Mt. 19:8/Mk. 10:4) }\end{array}$ \\
\hline
\end{tabular}

Thus the New Testament texts reflect a two-pronged shift towards a more Permissive attitude.

\section{The Protasis: Conditionality and Modal Force}

I hope the above discussion will have served to bring some clarity to the modal force of particular grammatical forms and lexical items. It has left some questions of clausal contingency 
unanswered, however. In particular, it has focused solely on the Permissive/Obligative apodosis of Deuteronomy 24:1. Here, we turn to the conditional protasis.

The subjective Volition to divorce, אם-לא תמצאדחן בעיניו ('If she doesn't find favour in his eyes') is only a secondary condition in Deuteronomy 24:1-the primary condition is the objective Offence, כי־מצא בה ערות דבר, 'because he has found some indecency [?] in her'.23 Thus one might paraphrase:

If he has found some indecency in her [Offence] and if she therefore doesn't find favour in his eyes [Volition], then he may/must write...

This compound condition 24 was dissected in at least two distinct ways by Rabbinic Judaism. On the one hand, Mishnaic legislation Obliged a husband to divorce his wife if she committed adultery, thus crossing directly from the Offence to (their Obligative reading of) the ruling itself, effectively reading:..... מצה בה ערות דבר וכתב,... 'If... he has found some indecency in her, then he must write...'.25 On the other כי־מצא בה מיס ערות דבר, by the very admission of R. Akiba, renders this Offence clause effectively synonymous with the Volition clause, אם־לא תמצאיחן בעיניו, 'If she doesn't find favour in his eyes', thus telescoping both conditions into the secondary Volition. ${ }^{26}$

${ }^{23}$ Contrast the second divorce (Dt. 24:3a), based purely on $\$$, for which Westbrook, 'Restoration of Marriage', 402, argues that "The verb "hate" is used to show that the action arose from a subjective motive and without objective grounds to justify it-and for this reason is blameworthy.' See, however, in response, also D.R. Hillers, 'Some Performative Utterances in the Bible', in D.P. Wright, D.N. Freeman and A. Hurvitz (eds.), Pomegranates and Golden Bells: Studies in Near Eastern Ritual, Law, and Literature in Honor of Jacob Milgrom (Winona Lake: Eisenbrauns, 1995) 757$66,765$.

${ }^{24}$ Compare that which spans Dt. 24:1-4, as discussed above.

$25 m$. Sota $4 ; 6: 1$.

${ }^{26} \mathrm{~m}$. Git 9:10, where the conservative, Shammaite reading (reflected in Mt.

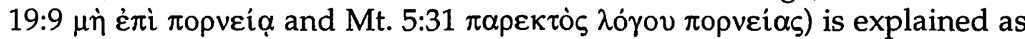
focusing on the word ערות, whilst the liberal, Hillelite reading (reflected in

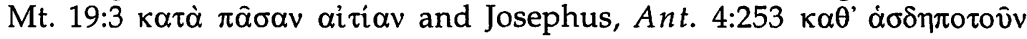


These two Rabbinic manipulations of the Old Testament text meant, on the one hand, that it was 'righteous' of Joseph to want to divorce Mary ( $c f$. Mt. 1:19), and on the other, that one could divorce one's wife for spoiling one's food (דבר) or simply if one found someone more beautiful (אם-לא תמצאיחן בעיניו).

The secondary condition, the husband's Volition to divorce (Dt. 24:1 $\square$ + modal yiqtōl), corresponds to the subjunctive 'Whoever would divorce' (ôs ôv à $\pi 0 \lambda v$ vin) in

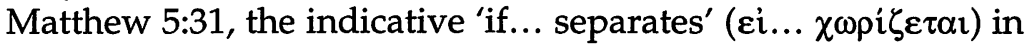
1 Corinthians 7:15 and the verb 'to want' (yvvoukòs...

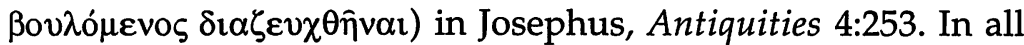
four of these texts, the modal strength of the apodosis is unspecified (wĕqătal and imperatives respectively), so how are we (or the Pharisees in Mt. 19, for that matter) to decide whether these texts permit or oblige one to divorce one's wife? The answer lies in the protasis.

In purely linguistic terms, a protasis based in the Hearer's volition can only govern Permission.27 Any other protasis can govern Permission or Obligation. Consider the sample sentences: 28

Moses said,

(1) 'If Bathsheba commits adultery [øVOL(H)],

then Uriah may [øvOL(S)] divorce her.'

(2) 'If Bathsheba commits adultery [øVOL(H)],

then Uriah must [+VOL(S)] divorce her.'

(3) If Uriah wants to divorce his wife $[+\mathrm{VOL}(\mathrm{H})]$,

then he may [ØVOL(S)] divorce her.'

$(4)^{*}$ 'If Uriah wants to divorce his wife $[+\mathrm{VOL}(\mathrm{H})]$,

then he must [+VOL(S)] divorce her.'

ai iias) is explained as focusing on the word דבר and (so R. Akiba) the Volition clause.

${ }^{27}$ Borrowing terms from the philosopher, J.L. Austin, one might say that 'Deontic cans are constitutionally iffy'; 'Ifs and Cans', in J.L. Austin, Philosophical Papers, ed. J.O. Urmson and G.J. Warnock (3rd ed.; Oxford: OUP, 1979) 205-232.

${ }^{28} \mathrm{VOL}=$ volition, $\mathrm{H}=$ Hearer, i.e. Uriah, $\mathrm{S}=$ Speaker, i.e. Moses, and ${ }^{*}=$ ungrammatical. The names are of course just examples. 
In (1), neither Speaker nor Hearer has expressed volition, so this ruling has no necessary outcome; combined with the Hearer's Volition, it may effect a divorce in Matthew 19:8// Mark 10:4. (2) and (3), by contrast, both express volition on behalf of one of the parties, and so both result necessarily in a divorce; (2) is the Mishnaic Obligation of divorce in the event of adultery, and (3) the Hillelite Permission of divorce for any reason. (4) is ungrammatical because it legitimates the Hearer's volition in the protasis, whilst delegitimating it in the apodosis. In our analysis of those Hebrew and Greek forms which are unspecified for modal strength, we can therefore apply the rules:

Rule 1: If the protasis expresses Volition [+VOL(H)], the apodosis is Permissive [ØVOL(S)].

Rule 2: If the apodosis is Obligative [+VOL(S)], the protasis expresses the Offence $[\varnothing \mathrm{VOL}(\mathrm{H})]$.

\section{Reading the Apodosis: Permissive or Obligative?}

As we have seen, Deuteronomy 24:1 has a compound protasis of primary Offence and secondary Volition.

If he has found some indecency in her [Offence] and if she therefore doesn't find favour in his eyes [Volition], then he may/must write...

Only Jesus's Permissive reading (Mt. 19:8) is compatible with both the Offence clause (as sample sentence (1) above) and the Volition clause (3). The Pharisees' Obligative reading (Mt. 19:7) is only compatible with an Offence protasis (Rule 2); it therefore corresponds exactly to the Mishnaic Obligation to divorce an adulteress. We may conclude that their question in v. 3,

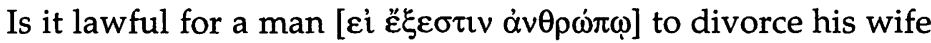

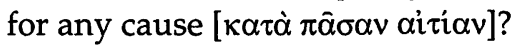

relates to the Hillelite Permission of divorce in the case of Volition, whilst their question in v. 7, 


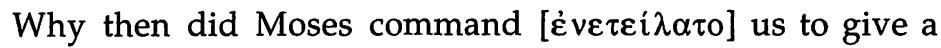
certificate of dismissal and to divorce her?

relates to the Mishnaic Obligation of divorce in the case of the specific Offence of adultery. The Pharisees have themselves redefined the condition as adultery by using the term 'command'. It is impossible to understand the Offence implicit in 'Why did Moses command us...?' (v. 7) as present in the preceding 'for any cause' (v. 3), since this would mean 'Moses commanded us to divorce our wives for any cause'!

Jesus's answer must be read in this light. In particular, it should be noted that he refers to 'the beginning' ('⿳亠口冋' ' $\dot{\rho} \chi \bar{\eta} \varsigma)$ to counter both their Permission of divorce for any reason (v. 3-4) and their Obligation of divorce in the case of adultery (v. 7-8). ${ }^{29}$ According to Jesus, then,

Moses said,

'If your wife has committed adultery [Offence], and if you therefore want to divorce her [Volition], then you may do so.'

but it wasn't like that to start with.

Jesus is therefore not redefining the Law in any way, but following the Pharisees' interpretation (v. 7) of ערות דבר as adultery, taking both the Offence and the husband's Volition as וכתב necessary conditions, and therefore (inevitably!) reading as Permissive. Both the Mishnaic Obligation to divorce an adulteress and the Hillelite Permission to divorce 'for any cause' are simply due to bad grammar, and are excluded by the wording of Deuteronomy 24:1. Jesus's 'new' contribution goes beyond all this, as he argues that the order of creation made no provision for divorce even in these circumstances.

${ }^{29}$ Compare the Qumran Damascus Document against divorce (or perhaps polygamy): CD 4:21 סוד הבריאה זכר ונקבה ברא אותם ('the foundation of creation is "male and female he created them"'). 


\section{Conclusion}

A new analysis of the structure of Deuteronomy 24:1-4 has shown that Moses did in fact issue a ruling on the procedure for divorce, rather than (as has been commonly held since the LXX) simply presupposing it. The wĕqātal form used admits the range of modal interpretation from Permissive 'may' to Obligative 'must'. This explains New Testament references to divorce, which either retain this ambiguity with third-person imperatives (Mt. 5:31; 1 Cor. 7:15; similarly Josephus, Ant. 4:253) or resolve it as 'may' (Mt. 19:8//Mk. 10:4) or 'must' (Mt. 19:7). The terminology used has generally been moderated

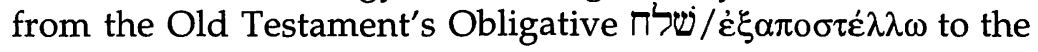
New Testament's Permissive $\alpha \dot{\alpha} 0 \lambda \hat{v} \omega$. Volitional conditional clauses have been shown to be incompatible with Obligative main clauses, so that the Permissive reading of Deuteronomy 24:1 (Mt. 19:8//Mk. 10:4) must be the correct one, and the Pharisees' Obligative reading in Matthew 19:7 must be both manipulative of the Old Testament text and even discontinuous with their own previous Permissive reading in v. 3 . This discontinuity also means that Jesus's Permissive reading relates not to the Hillelite Volition condition of v. 3, but to the Shammaite adultery condition of v. 7. Matthew 5:31 and Josephus, Antiquities 4:253 must also be Permissive. ${ }^{30}$

By reducing main-clause verbal forms (wëqātal), verbs

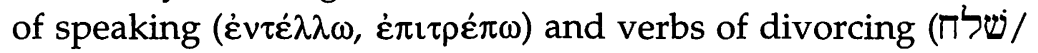
$\dot{\varepsilon} \xi \alpha \pi \circ \sigma \tau \dot{\varepsilon} \lambda \lambda \omega, \dot{\alpha} \pi \circ \lambda \dot{v} \omega)$ all to the two modal values of Obligation and Permission, and conditional protases to objective and subjective categories (Offence and Volition), it has been possible to clarify in a more systematic way than previously the relationships between Biblical divorce texts. Though diachronic linguistic study can certainly still clarify the relationships between the various verbs used for divorcing, and historical research may reveal the background to Pharisaical

${ }^{30} \mathrm{~A}$ still unresolved problem is the indicative-imperative sequence of

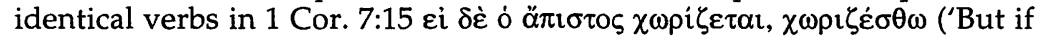
the unbeliever separates, let him separate'); one may need to think in terms of inceptive-imperative or real-attitudinal. 
interpretations of the Torah text, an economical linguistic model has produced a solid basis for such further study.

Finally, these conclusions will affect our reading of some related texts. They may illuminate the force of other

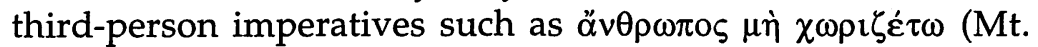
19:6//Mk. 10:9), which is clearly forcefully Prohibitive ('man must not separate'), though standardly rendered so weakly as to sound Expressive/Optative ('let man not separate'). ${ }^{31}$ Secondly, the closing comment,

Anyone who divorces his wife (except for unchastity) and marries another commits adultery,

which is present with variations in Matthew 5:32; 19:9; Mark 10:11-12 and Luke 16:18, will no longer be read as Jesus's 'new' contribution (see e.g. Mt. 5:32 NRSV 'but'), but as the natural extension of his reading of Deuteronomy 24. What is new, as Hays so powerfully demonstrates, 32 is Jesus's location of the Deuteronomic Law within the creational paradigm of marriage as a divine-and therefore binding-institution. ${ }^{33}$

\footnotetext{
31 Similarly, the 'commandments' in 1 Cor. 7:10 and 1 Jn. 4:21! ${ }^{32}$ Hays, ibid.

${ }^{33}$ The modal categories used here might be used in the interpretation of other imperative, subjunctive and optative forms, and of Deontic clause types, including: wishes (Mt. 26:39, 42; Jn. 17:21, 23), curses (Mt. 21:19// Mk. 11:14; Acts 1:20; 8:20; Rom. 11:9-10) and blessings (passim); dismissals, whether 'letting someone go' or 'sending someone away' (Mk. 11:6; Mk. 5:12//Mt. 8:31//Lk. 8:32; Mk. 7:29; Jn. 4:50; Acts 24:25), expressions of permission (Lk. 17:8), requests for permission (Acts 10:29; 21:37) and even a request for a command (Mt. 14:28). Applications of theological importance might include 1 Cor. 7:6 ('I say this as a concession, not as a command.'), 1 Cor. 6:12-13//10:23 ('Everything is permissible but not everything is beneficial.'), the various NT versions of Isa 6:10 ('lest they see with their eyes and hear with their ears'-Mt. 13:10-17; Mk. 4:11-12; Lk. 8:10; Jn. 12:37-41; Acts 28:24-28; Rom. 11:7-8) and discussions such as Rom. 14.
} 